\title{
Print versus Electronic Journal Use in Three Sci/Tech Disciplines: What's Going On Here?
}

\section{Tammy R. Siebenberg, Betty Galbraith, and Eileen E. Brady}

In 2003, an evaluation of journal use statistics at Washington State University was undertaken to determine if the selection of electronic journals in the Owen Science and Engineering Library was changing student and researchers' choice of journals. Use statistics showed that most print journals were being used more than they were prior to the advent of electronic journals. Generally, electronic journals were used heavily and the availability of electronic format greatly enhanced the total use of most titles. However, some electronic journals were used little or not at all, and there was a substantial increase in the use of some print titles.

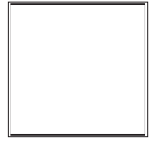

rom all around the library world, people are said to be changing from using paper journals to electronic journals (e-journals). According to one library assistant director, "faculty are 'happy as can be' to dial into a university's subscription from their office, and students 'almost always prefer to read an electronic journal.' Students will stand in line for the terminal rather than walk up one flight of stairs to get the paper copy." ${ }^{11}$ Finding few studies to support this, the authors decided to undertake their own study to see if the "common wisdom" was accurate for their library. ${ }^{2-4}$ Were patrons switching from the print journals they had used in the past to electronic titles (e-titles) regardless of title, just because a title was available electronically?

In 2001, Washington State University's Owen Science and Engineering Library had approximately 2,700 titles in electronic format. Some of the titles duplicated paper titles in the collection, but many of the e-titles, which had been acquired in package deals, had never been available before in the authors' library. The authors feared they might be funneling researchers and students to less "presti-

Tammy R. Siebenberg is the Information Literacy Coordinator in the Harold B. Lee Library at Brigham Young University; e-mail: tammy_siebenberg@byu.edu; Betty Galbraith is the Owen Collection Development Manager in the Owen Science and Engineering Library at Washington State University; e-mail: bettyg@wsu.edu; Eileen E. Brady is Manager, Owen Collection Preservation and Access, and Security in the Owen Science and Engineering Library at Washington State University; e-mail: brady@wsu.edu. When this article was written, Siebenberg was the Science/Engineering Librarian and Library Instruction Coordinator in the Owen Science and Engineering Library. 
gious" journals by the selection of titles in electronic format (e-format).

The authors decided to look at the use statistics for titles the library had in 1998, before it had e-journals online, and in 2001, when there was a good mix of electronic and paper journals. Moreover, by 2001, usage statistics, provided by the e-journal vendors, were available for many of the e-journals.

\section{Context}

Washington State University (WSU) is a land-grant institution with eleven libraries. Owen Science and Engineering Library (Owen) provides support to four thousand faculty and students with majors in the hard sciences, agriculture, and engineering, as well as general undergraduate support for students in other majors.

\section{Assumptions}

Among the assumptions in the library profession is that patrons will shift from journals unavailable in e-format to ones that are available in e-format. If a journal is available electronically, its use increases at the expense of comparable journals available only in paper. If comparable journals become available in e-format, titles available only in paper will have a decline in use in deference to the e-journals. In addition, when a paper journal becomes available in e-format, use will shift from paper to electronic.

\section{Need}

Several things were occurring simultaneously at Owen that precipitated a study of users' choice of journals and formats. First, the library was becoming heavily involved in big-package purchases and consortial purchases of e-journal titles. Thus, titles were being picked up that Owen previously could not afford or would not have selected for its clientele if given a choice. Second, the library's gate count had been dropping. In 2001, 30 percent fewer people entered Owen Library than in $1997 .{ }^{5}$ Third, dwindling resources forced the librarians to consider any method to save on journal purchases. This happened at a time when some publishers were starting to offer online-only (e-only) subscriptions at a reduced rate. Fourth, many standard titles were not yet available online or electronic access (e-access) was an expensive add-on to the print. Owen librarians needed to know if their choice of big packages was changing the titles that students and researchers were using. Should extra money be paid, instead, to get e-access to the high-quality titles Owen already offered?

\section{Methodology}

It was decided to compare uses of titles in 1998, before Owen had e-journals, to uses of the same titles in 2001, when substantial numbers of e-journals were available to users and use statistics were available from publishers. The authors decided not to use 2002 statistics in the study because, by then, budget cuts had forced them to cancel paper and shift to e-access, despite what the library's users might want. Embargoed (time-delayed e-access) titles were not an issue; there were none in the subject areas selected for the study.

Because Owen serves the science, technology, agriculture, and engineering needs of the WSU campus, it was decided to study applied and pure science areas. The authors looked at active title counts for the different disciplines and discovered that some were too disparate to permit valid comparisons of data. For example, agriculture had 553 active titles whereas environmental science had 28. The largest journal collections were in agriculture (553 titles) and biology (502 titles). However, agriculture could not be used because the electronic use sta- 
tistics (e-use statistics) were inflated by the many extension stations and county extension personnel using the e-journals from distant research sites. No other disciplines exhibited this phenomenon. Some disciplines did not have usable statistics because the e-use statistics were not supplied by the publisher. In other cases, too few titles added e-access between 1998 and 2001 to draw valid conclusions from the data.

Finally, the authors chose chemistry (90 titles), physics (121 titles), and mechanical and materials engineering (105 titles). Even in these disciplines, there were titles for which Owen had e-access, but for which the publishers did not supply statistics. Because these latter titles would skew the data, they were eliminated from the study. This left 277 titles in the study.

\section{Journal Use Statistics}

Continuous use statistics for paper journals had been kept in Owen since 1993. These statistics were used to guide collection decisions. Each reshelving of a current issue or bound volume, whether checked out or used in-house, counted as one use. Clearly, there was no way to know how many articles in an issue or volume had been read or whether only the table of contents had been perused. However, as pointed out by Deborah D. Blecic, Joan B. Fiscella, and Stephen E. Wiberley Jr., there is no way to know "that searchers read what they display" for e-format either. ${ }^{6}$ Signs were posted throughout the library asking patrons not to reshelve items because a journal use study was under way.

With the advent of e-journals, their use statistics were added to the database. Yearly paper and online use statistics were-and are-maintained in separate fields so librarians could track changes in usage patterns for each title. By us- ing two full years of data, it was hoped to minimize the inaccuracy inherent in using one or two months as was done in other studies. $^{7}$

Online journal publishers were requested to supply the required use statistics. Even though the librarians had e-use statistics from only 39 percent of the publishers, the statistics accounted for more than 99 percent of the e-titles to which the library subscribed. For ejournals, the library chose to use access to full-text articles as the measure of use. Although a comparison of print use statistics (flawed though they were) and e-use statistics may be decried as "mixing apples and oranges," this method was deliberately chosen for two reasons. First, although the librarians have always wanted to know how many articles have been read out of a journal, they have never been able to get anything but inhouse issue or volume use counts. The full-text statistic is getting closer to filling their needs. Second, when print journals cease to exist, as some librarians believe, the library would already be using the "best" use statistic from those offered by publishers. Recognizing these issues, the authors wanted to know if paper use statistics really dropped as radically as predicted.

\section{Data Evaluation}

A full explanation of the database and statistics collection process is available in "Journal Retention Decisions Incorporating Use-Statistics as a Measure of Value" by Betty Galbraith. ${ }^{8}$

The authors chose to look at several factors to see if use patterns among titles were changing and if the changes were indeed related to e-access. The basic questions were the following:

First, how did the use of print titles change between 1998 and 2001? How many titles without e-access had in- 
creased, decreased, or not changed? How many print titles with e-access had increased, decreased, or not changed? The print use of titles in 1998 were compared with the print use of those same titles in 2001. Using print use to print use evaluation compensated for the difference in the statistics used for paper in-house use versus electronic full-text article access statistics from the publishers. The authors felt that looking at just paper usage would allow them to see whether paper use was really dropping as e-access was being added and if the change related to whether that title also had e-access.

Second, how did the number of uses of titles change between 1998 and 2001, including both print and e-use statistics? The same questions as above were asked about increased, decreased, or the same use. Looking at these data, the authors expected to see that e-access would greatly increase the use of individual titles, but would this always be the case? Did titles for which there was no e-access also increase in use? Were there e-titles that were not being used? In order to determine whether there was a pattern related to e-access, the authors looked at total uses for each year in each category. Total uses were determined by adding paper uses for 2001 to e-use statistics for 2001. The authors then counted the number of titles that increased in use, decreased, or remained unchanged.

It was clear that simply noting that a title increased or decreased in use did not take into account the number of its uses. A title might have increased from one to two uses or from a hundred to two hundred uses, all of which represented a 100 percent increase in use. To better understand the data gathered, the authors calculated the sum of the uses of the titles. They also calculated the mean and median for each category to see how far afield the highs and lows were. ${ }^{9}$ In ad- dition, they wanted to compare changes over time among the journals, so they calculated the percentage change. ${ }^{10}$ Thus, unlike the DeGroote-Dorsch six-month study, which showed "users accessing electronic versions more that ten times as often as the print versions," the authors' comparison of data from 1998 and 2001 revealed that, in general, print use increased overall when e-access became

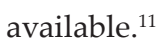

Because titles would be increasing and decreasing in use in widely varying amounts, some by as little as one use and some by as much as a hundred uses, the authors decided to look at the rankings to see if titles changed in relative use between the years. Titles were ranked by use for 1998. Then the authors looked to see if the rankings changed in 2001. If the rankings did change, how? How did the titles change in ranked use between 1998 and 2001, looking at only print access? Then, how did the titles change in ranked use between 1998 and 2001, including both print and electronic statistics? This time, new titles (those acquired after 1998) were included in the mix so that it would be possible to see where the titles that had no print would fall within the rankings. Would they fall among the more heavily used or the less heavily used? Would they change the rankings of those titles that only had print access? Because most would change somewhat, the authors wondered if these changes really would show what the authors wanted to know. Therefore, this information also was looked at in rankings by groups of ten. How many titles changed and yet remained in their own group of ten in each year? How many went up or down-one group, two groups, three groups, and so on? How was this related to e-access? Changes in 2001 were measured against 1998, the baseline year. 
Results

\section{Individual Subject Areas}

Chemistry

This study looked at eightyfive chemistry titles. Of those, sixty-six were in paper in both 1998 and 2001. By 2001, e-access had been added to sixty-one of the paper titles, leaving five in paper only. Moreover, one paper subscription (with e-access) had been added, as well as eighteen online-only titles. 1

Print use in 1998 was compared to print use in 2001 for paper-only titles and for titles in paper to which e-access had been added by 2001. Table 1 shows how the sixty-six paper titles changed.

None of the print-only titles dropped in use. Of the titles that had e-access, 44 percent dropped in print use and 52 percent of them increased in use. E-access did not always mean a drop in use of these print issues.

The authors then added the 2001 e-uses and noted the change in title use from 1998 to 2001. These figures are shown in table 2 . The availability of e-access resulted in a slight increase in the use of paper journals. Adding e-access to these titles did not automatically increase the use of every title; one actually decreased in use.

The number of uses varied widely from title to title. Tables 3, 6, 9, and 13 show the total number of uses for each category and year as collected in-house and received from vendors. The percentage of change

\section{TABLE 1}

in Print Uses of Chemistry Titles, 1998 and 2001 (by number of titles)

\begin{tabular}{|c|c|c|c|}
\hline Increased & Decreased & Unchanged & Total \\
\hline 4 & 0 & 1 & 5 \\
\hline 32 & 27 & 2 & 61 \\
\hline 36 & 27 & 3 & 66 \\
\hline
\end{tabular}

in print uses from 1998 to 2001 and the percentage of change in total uses (print plus online uses) from 1998 to 2001 also are included. The numbers in parentheses indicate the number of titles within the categories. (Note that 1998 print uses are the same as total uses because there were no e-journals in 1998.)

Lack of e-access did not reduce uses for print-only chemistry titles. In fact, print-only titles were used 57.5 percent more in 2001. When the sixty-one titles with e-access were added to the chemistry titles, there was a decline of only 2.1 percent in the uses of paper copies from 1998 to 2001. Nevertheless, 25.3 percent of the total 2001 uses of chemistry journals available were paper uses. This is an impressive figure when one considers that one reshelving of an issue or volume equals one use for paper and the viewing of one full-text article constituted one use for electronic.

Despite the addition of eighteen online-only titles by 2001, print uses remained strong as a proportion of total uses. The one new title available in both print and electronic format was so heavily used that it made up for the drop in use of other paper titles, resulting in a decline of only 0.8 percent. This particular title was selected specifically for the chemistry program, whereas the eighteen online-only titles came in packages. Some of the titles 


\begin{tabular}{|c|c|c|c|c|c|c|c|c|}
\hline \multicolumn{9}{|c|}{$\begin{array}{c}\text { TABLE } 3 \\
\text { Uses of Chemistry Titles (by number of uses) }\end{array}$} \\
\hline $\begin{array}{l}\text { Print } \\
\text { Uses } \\
1998\end{array}$ & $\begin{array}{l}\text { Print } \\
\text { Uses } \\
2001\end{array}$ & $\begin{array}{l}\text { Change } \\
\text { in Print } \\
\text { Uses }\end{array}$ & $\begin{array}{c}\text { Percent } \\
\text { Change } \\
\text { in Print } \\
\text { Uses }\end{array}$ & $\begin{array}{c}\text { E-uses } \\
2001\end{array}$ & $\begin{array}{l}\text { Total } \\
\text { Uses } \\
2001\end{array}$ & $\begin{array}{l}\text { Change } \\
\text { in Total } \\
\text { Uses }\end{array}$ & $\begin{array}{c}\text { Percent } \\
\text { Change } \\
\text { in Total } \\
\text { Uses }\end{array}$ & $\begin{array}{l}\text { Print Uses as } \\
\text { Percent of } 2001 \\
\text { Total Uses }\end{array}$ \\
\hline \multicolumn{9}{|c|}{ Print-only (5) } \\
\hline 259 & 408 & 149 & $57.5 \%$ & & 408 & 149 & $57.5 \%$ & $100.0 \%$ \\
\hline \multicolumn{9}{|c|}{ Print With E-access Added After 1998 (61) } \\
\hline 3,484 & 3,255 & -229 & $-6.6 \%$ & 10,790 & 14,045 & 10,561 & $303.1 \%$ & $23.2 \%$ \\
\hline \multicolumn{9}{|c|}{ All Print (66) } \\
\hline 3,743 & 3,663 & -80 & $-2.1 \%$ & 10,790 & 14,453 & 10,710 & $286.1 \%$ & $25.3 \%$ \\
\hline \multicolumn{9}{|c|}{ All Print Plus E-only (85) } \\
\hline 3,743 & 3,714 & -29 & $-0.8 \%$ & 12,312 & 16,026 & 12,283 & $328.2 \%$ & $23.2 \%$ \\
\hline
\end{tabular}

had very few uses. This may show that just because journals are available online, patrons do not necessarily use them in that format. ${ }^{12}$ As expected, the addition of the new e-only titles resulted in an overall increase in total uses; as shown in table 3 , the sixty-six titles available in print showed a 286.1 percent increase in use. When e-only titles were included in the calculations, the data showed an increase of 328.2 percent.

\section{Mechanical and Materials Engineering}

Ninety-one mechanical and materials engineering (MME) titles were included in the study. Of those, forty-seven were in print in both 1998 and 2001. By 2001, twenty-six of the subscriptions remained in paper-only format, whereas twentyone were for both paper and e-access. One paper-only subscription and forty-three onlineonly subscriptions were added.

As with the chemistry titles, the authors compared print uses in 1998 to print uses in 2001 for the twentysix titles in paper-only and the twenty-one titles in pa- per with e-access. Table 4 shows how use of these forty-seven titles changed.

In this discipline, the study showed that electronic availability resulted in an increase in the use of paper journals. As in the chemistry study, e-access did not guarantee use of a title.

As shown in table 5, the addition of e-access clearly increased the total use of all titles with e-access. At the same time, only 42 percent of the titles that lacked e-access dropped in print use.

Table 6 shows the number of uses for groups of MME titles along with the percentage of change in print uses from 1998 to 2001 and the percentage of change in total uses from 1998 to 2001. As expected, adding e-access increased total uses of MME journals, as it did with the chemistry journals.

\begin{tabular}{|l|c|c|c|c|}
\hline \multicolumn{5}{|c|}{ TABLE 4 } \\
Change in Print Uses of MME Titles, 1998 and \\
2001 (by number of titles)
\end{tabular}


From 1998 to 2001, use of MME print-only journals increased 12.9 percent, showing that for this discipline e-access did not draw use away from important titles still available only in print. With the addition of e-access to print journals, print uses of all MME

\begin{tabular}{|c|c|c|c|c|}
\hline \multicolumn{5}{|c|}{$\begin{array}{c}\text { TABLE 5 } \\
\text { Change in Total Uses of MME Titles, } 1998 \text { and } \\
2001 \text { (by number of titles) }\end{array}$} \\
\hline & Increased & Decreased & Unchanged & Total \\
\hline Print-only & 11 & 11 & 4 & 26 \\
\hline $\begin{array}{l}\text { Print with } \\
\text { e-access }\end{array}$ & 21 & 0 & 0 & 21 \\
\hline Total & 32 & 11 & 4 & 47 \\
\hline
\end{tabular}
journals actually increased 51.2 percent and journals that were available in both formats saw print use nearly double, with an increase of 93.6 percent. Whereas e-access more than doubled the uses of MME titles, overall print uses still accounted for 39.6 percent of all uses.

By 2001, one new print-only title and forty-three online-only titles had been added to the library's collection. After adding in statistics for these additions, print uses dropped to 22.8 percent of total uses but still made up over one-fifth of the total uses of MME titles. Interestingly, the addition of new e-journals nearly doubled total uses of MME titles and the titles available in print showed a 282.3 percent increase in use. When the e-only titles were included in the calculations, the data show an increase of 563.5 percent.

\section{Physics}

The authors examined 101 physics titles as part of the study, 67 of which were in paper in both 1998 and 2001. By 2001, e-access had been added to fifty-six of the titles, leaving eleven as paper-only subscriptions. One new paper-only subscription, two new paper-plus-online subscriptions, and thirty-one online-only subscriptions also had been added. The change in use of print copies of physics journals from 1998 to 2001 is shown in table 7 .

Lack of e-access did not cause print uses to drop for two-thirds of the printonly journals. Another way to look at it is that e-access did not ensure that a title would change use in either format. This may reflect the findings of Ann Peterson Bishop that e-journals are not used the first year they are available. ${ }^{13}$ Significantly, print use increased for more than half of

\begin{tabular}{|c|c|c|c|c|c|c|c|c|}
\hline & & & $\mathrm{s}$ of $\mathrm{MI}$ & $\begin{array}{r}\text { TA } \\
\text { E Title }\end{array}$ & $\begin{array}{l}\text { 3LE } 6 \\
\text { s (by I }\end{array}$ & mber of & Ises) & \\
\hline $\begin{array}{l}\text { Print } \\
\text { Uses } \\
1998\end{array}$ & $\begin{array}{l}\text { Print } \\
\text { Uses } \\
2001\end{array}$ & $\begin{array}{c}\text { Change } \\
\text { in Print } \\
\text { Uses }\end{array}$ & $\begin{array}{c}\text { Percent } \\
\text { Change } \\
\text { in Print } \\
\text { Uses }\end{array}$ & $\begin{array}{c}\text { E-uses } \\
2001\end{array}$ & $\begin{array}{l}\text { Total } \\
\text { Uses } \\
2001\end{array}$ & $\begin{array}{c}\text { Change } \\
\text { in Total } \\
\text { Uses }\end{array}$ & $\begin{array}{c}\text { Percent } \\
\text { Change } \\
\text { in Total } \\
\text { Uses }\end{array}$ & $\begin{array}{l}\text { Print Uses as } \\
\text { Percent of } 2001 \\
\text { Total Uses }\end{array}$ \\
\hline Print- & nly $(26$ & & & & & & & \\
\hline 365 & 412 & 47 & $12.9 \%$ & & 412 & 47 & $12.9 \%$ & $100.0 \%$ \\
\hline Print & ith $E$ - & ccess $A d$ & d After & 98 (21) & & & & \\
\hline 330 & 639 & 309 & $93.6 \%$ & 1,606 & 2,245 & 1,915 & $580.3 \%$ & $28.5 \%$ \\
\hline All Pr & t (47) & & & & & & & \\
\hline 695 & 1,051 & 356 & $51.2 \%$ & 1,606 & 2,657 & 1,962 & $282.3 \%$ & $39.6 \%$ \\
\hline All Pr & t Plus & E-only (9 & & & & & & \\
\hline 695 & 1,052 & 357 & $51.4 \%$ & 3,559 & 4,611 & 3,916 & $563.5 \%$ & $22.8 \%$ \\
\hline
\end{tabular}




\begin{tabular}{|l|c|c|c|c|}
\hline \multicolumn{5}{|c|}{ TABLE 7} \\
Change in Print Uses of Physics Titles, 1998 and \\
2001 (by number of titles)
\end{tabular}

of titles, the percentages of change from tables 3,6 , and 9 can be compared, as shown in table 10.

Between 1998 and 2001, print uses of print-only titles increased in all three disciples. Although the percentage of change in print uses for all chemistry

the titles that added e-access. The addition of e-use to print use in 2001 resulted in the changes in total use shown in table 8.

As can be seen, titles with e-access increased in total use most of the time, but this did not occur in nine of sixty-seven instances. This means that 13 percent of titles with e-access either did not increase in use or dropped in use.

As with the other two subject areas examined, the number of uses for individual titles spanned a wide range. Table 9 shows the number of print and e-uses for physics titles during the study years. The percentage of change in print uses and percentage of change in total uses also are shown.

Print use accounted for more than one-third of all uses in this group of titles. From 1998 to 2001, use of the sixty-seven print-format physics titles increased by 39.6 percent. Uses of print-only titles increased by nearly 50 percent.

Adding thirty-four new titles (only one of which was print only) resulted in a print use share of 27.5 percent, a drop of 6.3 percent. This was far less of a change than one would expect after adding 50 percent more titles to the collection.

\section{Comparisons}

Although usage figures cannot be compared among the three disciplines because of differences in numbers print titles dropped slightly, both MME and physics showed substantial increases in print uses. As one would expect, the addition of e-access resulted in large increases in total use; nevertheless, paper uses in 2001 continued to account for more than 25 percent of all uses.

In addition to comparing the three subject groups, the authors were interested in comparing all print-only journals to all print with e-access journals without regard to subject area. These comparisons in print use are shown in table 11.

Interestingly, for all three disciplines, 52 percent of the print-only titles increased in print use and 56 percent of the print with e-access titles increased in print use. This is only a four percent difference, which may suggest that there is a value to the physical version of the journal that e-access does not possess. Perhaps clarity of graphics or other content of the print version not reproduced in the electronic (e.g., advertisements, job announcements, letters, or book reviews) is valued by the users.

Table 12 compares the changes between print-only titles and print titles with e-access when total uses are considered.

\section{TABLE 8}

\section{Change in Total Uses of Physics Titles, 1998 and 2001 (by number of titles)}

\begin{tabular}{|l|c|c|c|c|}
\hline \hline & Increased & Decreased & Unchanged & Total \\
\hline Print-only & 7 & 4 & 0 & 11 \\
\hline $\begin{array}{l}\text { Print with } \\
\text { e-access }\end{array}$ & 51 & 3 & 2 & 56 \\
\hline Total & 58 & 7 & 2 & 67 \\
\hline
\end{tabular}




\begin{tabular}{|c|c|c|c|c|c|c|c|c|}
\hline \multicolumn{9}{|c|}{$\begin{array}{c}\text { TABLE } 9 \\
\text { Uses of Physics Titles (by number of uses) }\end{array}$} \\
\hline $\begin{array}{l}\text { Print } \\
\text { Uses } \\
1998\end{array}$ & $\begin{array}{l}\text { Print } \\
\text { Uses } \\
2001\end{array}$ & $\begin{array}{l}\text { Change } \\
\text { in Print } \\
\text { Uses }\end{array}$ & $\begin{array}{c}\text { Percent } \\
\text { Change } \\
\text { in Print } \\
\text { Uses }\end{array}$ & $\begin{array}{c}\text { E-uses } \\
2001\end{array}$ & $\begin{array}{l}\text { Total } \\
\text { Uses } \\
2001\end{array}$ & $\begin{array}{l}\text { Change } \\
\text { in Total } \\
\text { Uses }\end{array}$ & $\begin{array}{c}\text { Percent } \\
\text { Change } \\
\text { in Total } \\
\text { Uses }\end{array}$ & $\begin{array}{l}\text { Print Uses as } \\
\text { Percent of } 2001 \\
\text { Total Uses }\end{array}$ \\
\hline \multicolumn{9}{|c|}{ Print-only (11) } \\
\hline 137 & 202 & 65 & $47.4 \%$ & & 202 & 65 & $47.4 \%$ & $100.0 \%$ \\
\hline \multicolumn{9}{|c|}{ Print With E-access Added After 1998 (56) } \\
\hline 1,861 & 2,587 & 726 & $39.0 \%$ & 5,473 & 8,060 & 6,199 & $333.1 \%$ & $32.1 \%$ \\
\hline \multicolumn{9}{|c|}{ All Print (67) } \\
\hline 1,998 & 2,789 & 791 & $39.6 \%$ & 5,473 & 8,262 & 6,264 & $313.5 \%$ & $33.8 \%$ \\
\hline \multicolumn{9}{|c|}{ All Print Plus E-only (101) } \\
\hline 1,998 & 2,799 & 801 & $40.1 \%$ & 7,390 & 10,189 & 8,191 & $410.0 \%$ & $27.5 \%$ \\
\hline
\end{tabular}

In this case 95.6 percent of the print titles with e-access increased in use. However, not every title with e-access increased in use; six of 138 titles (4\%) remained the same or dropped in use. The fact that some titles decreased or remained unchanged, and 16 percent of the titles in the study showed minimal use, despite having e-access, supports David Goodman's research, which showed that "mere availability did not result in their extensive use. This shows that the electronic format can be a delivery system for increasing appropriate use, not a way to encourage the patrons to use articles they do not need." 14
Table 13 looks at actual uses of titles, in every format, in all three disciplines.

Even with the addition of electronic access to print journals, the print versions accounted for nearly 30 percent of all uses. Print-only uses increased by 34.3 percent. All print titles (with and without e-access) showed an increase in use of 16.6 percent of print versions and an increase in total uses of 294.2 percent. Adding e-access nearly tripled the use of journals in these subject areas.

As discussed above, after 1998 the library added two new print-only titles, three print with e-access, and ninety-two new e-only titles to its collection. This

\section{TABLE 10}

Comparison of Percent Change in Uses Among Disciplines (print-only and print with e-access titles)

\begin{tabular}{|l|c|c|c|c|c|}
\hline \hline & $\begin{array}{c}\text { Percent } \\
\text { Change in } \\
\text { Print Uses } \\
\text { of Print- } \\
\text { only Titles }\end{array}$ & $\begin{array}{c}\text { Percent } \\
\text { Change in } \\
\text { Print Uses of } \\
\text { Print With } \\
\text { E-access } \\
\text { Titles }\end{array}$ & $\begin{array}{c}\text { Percent } \\
\text { Change in } \\
\text { Print Uses } \\
\text { of All Print } \\
\text { Titles }\end{array}$ & $\begin{array}{c}\text { Percent } \\
\text { Change in } \\
\text { Total Uses } \\
\text { of All Print } \\
\text { Titles }\end{array}$ & $\begin{array}{c}\text { Print Uses } \\
\text { as Percent } \\
\text { of 2001 } \\
\text { Total Uses } \\
\text { of All Print } \\
\text { Titles }\end{array}$ \\
\hline Chemistry & $57.5 \%$ & $-6.6 \%$ & $-2.1 \%$ & $286.1 \%$ & $25.3 \%$ \\
\hline MME & $12.9 \%$ & $93.6 \%$ & $51.2 \%$ & $282.3 \%$ & $39.6 \%$ \\
\hline Physics & $47.4 \%$ & $39.0 \%$ & $39.6 \%$ & $313.5 \%$ & $33.8 \%$ \\
\hline
\end{tabular}




\begin{tabular}{|l|c|c|c|c|}
\hline \multicolumn{5}{|c|}{ TABLE 11 } \\
$\begin{array}{r}\text { Change in Print Uses of Titles For All Disciplines, } \\
\text { 1998 and } 2001 \\
\text { (by number of titles) }\end{array}$ \\
\hline \hline & Increased & Decreased & Unchanged & Total \\
\hline Print-only & 22 & 15 & 5 & 42 \\
\hline $\begin{array}{l}\text { Print with } \\
\text { e-access }\end{array}$ & 77 & 56 & 5 & 138 \\
\hline Total & 99 & 71 & 10 & 180 \\
\hline
\end{tabular}

the board. This study suggests that users' migration from paper to e-use is dependent on the subject area. Steve Hiller's 2001 study at the University of Washington showed a distinct difference in use by broad academic areas but did not go to the dis-

brought the collection to 44 print-only titles, 141 print with e-access, and 92 eonly titles for a total of 277 titles. After adding the new titles to the calculations, the print versions still accounted for 24.5 percent of the journal uses.

While reviewing the data, the authors noted that one chemistry, one MME, and five physics e-only titles showed no uses in 2001. Eight other e-only titles had only two or three uses. This apparently answered the question of whether the library's faculty and students would use an e-journal just because it was available. As noted in the analysis by title, it is reasonable to assume that users are selecting their sources for reasons other than electronic availability.

\section{Results of Ranking Evaluation}

Evaluating ranking changes of the journals based on paper use in each year yielded no conclusive relationship between changes in ranking for titles that had e-access and those that did not have e-access. Neither was the relationship changed when the authors looked at the changes between print use in 1998 and total use in 2001. No new insights were gained from this analysis. ${ }^{15}$

\section{Conclusions}

The popular lore/common wisdom that people are changing from using print journals to electronic journals is not true across cipline/subject level used in this study. ${ }^{16}$ It may be worth noting that two of the studies ${ }^{17,18}$ reporting e-use as more than ten times the paper use were conducted at medical libraries where the time-sensitive nature of many queries may have been a factor. $^{19}$

Online availability definitely increased total use of journals. The MME and the physics subject areas experienced substantial increases in print uses. Because some titles with e-access declined in overall use, one can say that e-access does not guarantee that a title will be heavily used. It appears that quality and pertinence are still the dominant factors in journal selection by the library user. Although titles were being canceled every year during the period of this study, the authors do not believe this had an impact on the study because the titles being canceled had six or fewer uses per year.

Strikingly, although the gate count dropped and e-access greatly increased, the use of print journals did not drop. Despite the authors' assumptions that e-access and full-text databases would cause use of paper to decrease, e-access

\section{TABLE 12}

Change in Total Uses of Titles for All Disciplines, 1998 and 2001 (by number of titles)

\begin{tabular}{|l|c|c|c|c|}
\hline \hline & Increased & Decreased & Unchanged & Total \\
\hline Print-only & 22 & 15 & 5 & 42 \\
\hline $\begin{array}{l}\text { Print with } \\
\text { e-access }\end{array}$ & 132 & 4 & 2 & 138 \\
\hline Total & 154 & 19 & 7 & 180 \\
\hline
\end{tabular}




\begin{tabular}{|c|c|c|c|c|c|c|c|c|}
\hline & & ses of $T$ & les for $\mathrm{A}$ & $\begin{array}{l}\text { TABL } \\
\text { I Discip }\end{array}$ & $\begin{array}{l}13 \\
\text { ines }(b\end{array}$ & numbe & of uses) & \\
\hline $\begin{array}{l}\text { Print } \\
\text { Uses } \\
1998\end{array}$ & $\begin{array}{c}\text { Print } \\
\text { Uses } \\
2001\end{array}$ & $\begin{array}{c}\text { Change } \\
\text { in Print } \\
\text { Uses }\end{array}$ & $\begin{array}{c}\text { Percent } \\
\text { Change } \\
\text { in Print } \\
\text { Uses }\end{array}$ & $\begin{array}{c}\text { E-uses } \\
2001\end{array}$ & $\begin{array}{l}\text { Total } \\
\text { Uses } \\
2001\end{array}$ & $\begin{array}{c}\text { Change } \\
\text { in Total } \\
\text { Uses }\end{array}$ & $\begin{array}{c}\text { Percent } \\
\text { Change } \\
\text { in Total } \\
\text { Uses }\end{array}$ & $\begin{array}{c}\text { Print Uses } \\
\text { as Percent } \\
\text { of } 2001 \\
\text { Total Uses }\end{array}$ \\
\hline Print- & only (42 & & & & & & & \\
\hline 761 & 1,022 & 261 & $34.3 \%$ & & 1,022 & 261 & $34.3 \%$ & $100.0 \%$ \\
\hline Print & vith e-a & ess adde & after 199 & (138) & & & & \\
\hline 5,675 & 6,481 & 806 & $14.2 \%$ & 17,869 & 24,350 & 18,675 & $329.1 \%$ & $26.6 \%$ \\
\hline All pr & nt (180) & & & & & & & \\
\hline 6,436 & 7,503 & 1,067 & $16.6 \%$ & 17,869 & 25,372 & 18,936 & $294.2 \%$ & $29.6 \%$ \\
\hline All pr & nt plus & only (27) & & & & & & \\
\hline 6,436 & 7,565 & 1,129 & $17.5 \%$ & 23,261 & 30,826 & 24,390 & $379.0 \%$ & $24.5 \%$ \\
\hline
\end{tabular}

actually appears to provide greater access to print. Perhaps this is because databases make it easier to find older articles not yet online in full text and to find references to print-only articles from office and home computers.

Several other factors may have influenced the increased use of the print collection. Many articles from supplements or special issues are cited in databases but are available only in paper. Theme issues are difficult to identify from online searches. When theme issues are identified, they may draw users to look at the print versions. Other users have found that sometimes online images, such as plates and spectrographs, are not usable. Also, PDF quality in some journals is particularly poor.
Perhaps another factor is the growing concern among faculty members that students rely too heavily on electronic documents. The authors have noted that some are now giving assignments specifically designed to direct students to print. As one faculty member expressed it, "Print is the doorway through which students enter the field in its broadest context, and understand the scope of the field. Electronic is how they find specific bits of information." ${ }^{20}$

It appears that e-access increased paper use at Washington State University. However, results may vary from institution to institution. It would be important for each institution to do its own study to determine whether these findings apply to its collection.

\section{Notes}

1. Alison Buckholtz, "Electronic Genesis: E-journals in the Sciences," Academe 85, no. 5 (Sept./Oct. 1999): 65-68.

2. Sandra L. DeGroote and Josephine L. Dorsch, “Online Journals: Impact on Print Journal Usage," Bulletin of the Medical Library Association 84, no. 4 (Oct. 2001): 372-78.

3. David H. Morse and William A. Clintworth, "Comparing Patterns of Print and Electronic Journal Use in an Academic Health Science Library," Issues in Science and Technology Librarianship (fall 2000), available online at http://www.istl.org/00-fall/retereed.html.

4 Sally A. Rogers, "Electronic Journal Usage at Ohio State University," College E Research Libraries 62, no. 1 (Jan. 2001): 25-34.

5. Part of this drop was due to the fact that the ESL (English as a Second Language) program that had been housed in the library moved out of the building in early 2000. 
6. Deborah D. Blecic, Joan B. Fiscella, and Stephen E. Wiberley Jr., “The Measurement of Use of Web-based Information Resources: An Early Look at Vendor-supplied Data," College E Research Libraries 62, no. 9 (Sept. 2001): 434-53.

7. Ibid.

8. Betty Galbraith, "Journal Retention Decisions Incorporating Use-Statistics as a Measure of Value," Collection Management 27, no. 1 (2002): 79-90.

9. The means and medians data are available upon request.

10. The authors used the formula (B-A)/A where A is the number of uses in 1998 and $B$ is the number of uses in 2001.

11. DeGroote and Dorsch, "Online Journals," 373-78.

12. David Goodman, "A Year without Print at Princeton, and What We Plan Next," Learned Publishing 15, no. 1 (Jan. 2002): 43-50.

13. Ann Peterson Bishop, "Logins and Bailouts: Measuring Access, Use, and Success in Digital Libraries," Journal of Electronic Publishing 4 (Dec. 1998), available online at http://www.press.umich. edu/jep/04-02/bishop.html.

14. Goodman, "A Year without Print at Princeton, and What We Plan Next."

15. Statistics are available upon request.

16. Steve Hiller, "How Different Are They? A Comparison by Academic Area of Library Use, Priorities, and Information Needs at the University of Washington," Issues in Science and Technology Librarianship (winter 2002), available online at http://www.istl.org/02-winter/article1.html.

17. Morse and Clintworth, "Comparing Patterns of Print and Electronic Journal Use in an Academic Health Science Library."

18. DeGroote and Dorsch, "Online Journals," 372-78.

19. David Pullinger, "Academics and the New Information Environment: The Impact of Local Factors on Use of Electronic Journals," Journal of Information Science 25, no. 2 (1999): 164-72.

20. Kenneth V. Kardong, Ph.D., School of Biological Sciences, Washington State University, personal conversation with Betty Galbraith, 2003. 